\title{
Distant Site Effects of Ingested Prebiotics
}

\author{
Stephanie Collins ${ }^{1}$ and Gregor Reid ${ }^{1,2, *}$ \\ 1 Department of Microbiology and Immunology, The University of Western Ontario, \\ London, ON N6A 5C1, Canada; scolli69@uwo.ca \\ 2 Centre for Human Microbiome and Probiotics, Lawson Health Research Institute, 268 Grosvenor St., \\ London, ON N6A 4V2, Canada \\ * Correspondence: gregor@uwo.ca; Tel.: +1-519-646-6100 (ext. 65256)
}

Received: 20 July 2016; Accepted: 23 August 2016; Published: 26 August 2016

\begin{abstract}
The gut microbiome is being more widely recognized for its association with positive health outcomes, including those distant to the gastrointestinal system. This has given the ability to maintain and restore microbial homeostasis a new significance. Prebiotic compounds are appealing for this purpose as they are generally food-grade substances only degraded by microbes, such as bifidobacteria and lactobacilli, from which beneficial short-chain fatty acids are produced. Saccharides such as inulin and other fructo-oligosaccharides, galactooligosaccharides, and polydextrose have been widely used to improve gastrointestinal outcomes, but they appear to also influence distant sites. This review examined the effects of prebiotics on bone strength, neural and cognitive processes, immune functioning, skin, and serum lipid profile. The mode of action is in part affected by intestinal permeability and by fermentation products reaching target cells. As the types of prebiotics available diversify, so too will our understanding of the range of microbes able to degrade them, and the extent to which body sites can be impacted by their consumption.
\end{abstract}

Keywords: prebiotics; microbiome; bone; immune; cardiovascular; brain

\section{Introduction}

The human colon harbours $10^{11}-10^{12}$ live microorganisms per gram that, along with those in the small intestine, comprise the gut microbiota. In healthy individuals, this vast community acts symbiotically with the host to improve intestinal integrity, metabolism, and compete against pathogenic organisms. Lactic acid-producing Bifidobacterium and Lactobacillus genera have been regarded for their beneficial effects on the host, notably by their expression of immunomodulatory and pathogen-antagonistic molecules [1]. The targeted metabolism of select compounds by these commensal organisms to provide health benefits has been coined the "prebiotic effect" [2]. Prebiotics are defined as dietary fibers that are selectively fermented by beneficial microbes of the intestine. Unlike probiotics that require administration of exogenous microbes, prebiotics take advantage of the commensals already present in the host to degrade their otherwise indigestible bonds and support microbial survival [2,3]. Of note, it usually requires 5 grams or more to produce sufficient fermentation to benefit the host.

A wide variety of compounds have been studied for their prebiotic attributes. Various chain length oligosaccharides are the most common, including fructo-oligosaccharides (FOS) and galacto-oligosaccharides (GOS)/trans-galactooligosaccharides (TOS). FOS are found in several naturally occurring foods including artichokes, asparagus, garlic, and wheat. Their structure consists of a terminal glucose residue connected to a chain of $\beta(2,1)$-linked fructose residues. Inulin refers to highly polymerized FOS, containing at least 10 sugar monomers, and anything shorter is termed oligofructose. Also terminated by a glucose monomer, GOS/TOS comprise repeating units of galactose linked by $\beta(1,4)$ or $\beta(1,6)$ bonds, usually $2-8$ residues in length. Other less common oligosaccharides include 
polydextrose / $\beta$-glucans, which are linear or branched polymers of glucose, chains of xylose monomers denoted as xylo-oligosaccharides (XOS), and pectin-derived acidic oligosaccharides (pAOS), which are undefined oligosaccharide structures formed by partial enzymatic digestion of plant pectins [4]. Tri-, di- and even monosaccharides may be used as prebiotics, as long as they contain host-indigestible bonds. Some examples are raffinose, lactulose, and monomers L-rhamnose and arabinose. Lastly, other atypical compounds such as sugar alcohols (e.g., lactitol) and the cyclic disaccharide di-fructose anhydride III have been used as prebiotics.

Depending on the structure and combination of prebiotic compounds administered to the individual, effects on the microbiome will vary. In general, the selective fermentation of prebiotics by bifidobacteria and lactobacilli will increase numbers of these commensals while displacing other neutral or pathogenic organisms, overall supporting a symbiotic gut microbiota composition [5]. Additionally, this process alters the metabolism and activity of gut microbes, often lowering colonic $\mathrm{pH}$ due to acidic fermentation products such as lactate and short chain fatty acids (SCFAs) butyrate, acetate, and propionate. The fermentation products preferentially produced by these microbes depend on the prebiotic's structure and the bacterial communities present $[6,7]$, since some organisms utilize by-products from the degradation of more complex carbohydrates [8]. In turn, this determines what effects the prebiotic will have on host health in the gut and at distant sites.

Butyrate is known to exhibit beneficial properties in the gut since it supports the growth of intestinal epithelium, but its benefits are not limited there [9]. Butyrate and other SCFAs are considered the enactors for prebiotic effects elsewhere in the body due to their ability to pass through enterocytes into circulation [10]. This is crucial for highly polymerized or branched oligosaccharides that may only pass through epithelium in small amounts when highly concentrated in the intestinal lumen [11]. Ultimately either the prebiotic or its metabolites are required to enact changes apart from the gastrointestinal system, but there remains much more to be known about how these molecules specifically act upon the immune, circulatory, and neural systems. For this reason, research on prebiotics' influence on human health is burgeoning with exciting new findings.

Therefore, the purpose of this review is to examine the current evidence of how prebiotics impact distant sites, what is known about their mechanisms of action, and what potential exists to exploit these applications.

\section{Bone Density and Strength}

Osteoporosis is a condition that reduces bone density and strength, thereby increasing risk of fracture. It is especially prevalent in postmenopausal women and is magnified with age, as osteoporosis affects approximately $10 \%$ of women aged 60 up to almost $70 \%$ of women aged 90 [12]. To counter this, women are encouraged to increase their intake of minerals such as calcium and magnesium to counter bone loss. However, the finding that SCFAs modulate nutrient absorption and intestinal permeability [8] has opened up the possibility of using prebiotics to enhance calcium and magnesium absorption from the intestinal lumen, ultimately increasing bone regeneration and preventing osteoporosis.

Several rat models have demonstrated that GOS intake improves calcium absorption, retention, bone density, and strength $[13,14]$. The most notable benefits were reported in ovariectomized (OVX) rats, a model for the hormonal changes at menopause, which are a key risk factor for developing osteoporosis. Feeding these rats 5.0-5.5 g/100 g inulin and oligofructose daily for several weeks restores calcium and magnesium absorption capabilities and positively affects indicators for bone health such as strength and density $[15,16]$. More acutely, polydextrose can also enhance calcium and magnesium absorption [15]. Both long and short term bone benefits have been observed for OVX rats fed $5 \%$ per weight GOS, including improved calcium uptake into circulation and bone, and femur and tibia weights [17]. Another non-digestible compound not typically considered for prebiotic usage, di-fructose anhydride III, at a mere 3\% supplement to mouse diet, improved bone mineralization, calcium and magnesium uptake and bone strength in OVX rats after four weeks $[18,19]$. 
In human studies, failure to account for variation in diet and utilize a reasonably homogenous cohort, has meant that effects are much less pronounced. Nevertheless, such studies have shown mostly positive changes in mineral absorption [20-22]. A summary of human prebiotic trials for bone health is shown in Table 1. Postmenopausal women have been the focus of many human trials because of their particular risk in experiencing bone loss. Oligofructose-inulin blend has been shown to improve calcium and magnesium absorption, distinctly in individuals whose bone density was low prior to treatment [23]. However calcium uptake was not benefitted by oligofructose consumption in a study of early menopause, possibly because of the small sample size of 12 and large variation in mineral absorption at this stage of menopause [20,24]. Another study observed a $42 \%$ increase in calcium absorption following 3 months of chicory fructan administration [25], while TOS and lactulose have enhanced calcium uptake by $16 \%[26,27]$.

Adolescents and young adults also require successful mineral uptake and bone formation because of their rapidly growing bodies. An early study of teenage boys consuming 15 daily grams of inulin, FOS, or GOS observed no differences in calcium absorption after 3 weeks [28]. Scholz-Ahrens et al. [22] suggested that the lack of significant improvements in circulating calcium could be attributed to either insufficient dosage or time allotted before urine collection. Since prebiotics are typically not digested by the host or bacteria in the small intestine, but are instead fermented in the colon, it takes greater than the typically employed $24 \mathrm{~h}$ for prebiotics to reach and interact with colonic microbes. As a proof of principle, consumption of oligofructose and inulin-type fructans by teenagers, allowing at least $36 \mathrm{~h}$ of induction before final samples were taken, significantly improved calcium absorption [29-31].

In terms of the applicability of this enhanced uptake of bone minerals to actual improved bone density and health, the results are contentious. In two of the studies mentioned above on postmenopausal women, markers of bone remodelling and formation are unchanged or reduced with FOS, despite improving mineral uptake [24,25]. In contrast, a recent trial concluded that long-term FOS consumption has no effect on bone density but improves turnover, especially in women with osteopenia [32]. Similarly to another trial, only individuals with improved mineral uptake had improved bone metabolism in this cohort [23], suggesting that at-risk individuals are deficient in their ability to absorb calcium. It would be worth assessing the gut microbiota and barrier function of responders and non-responders to see if this explains the differences [33]. Interestingly, prebiotic interventions for bone density might be more effective in children or young adults than postmenopausal women, given that $8 \mathrm{~g}$ daily inulin for one year significantly increased bone mass and density throughout the teenage skeleton [29]. This makes a case for recommending prebiotics for individuals at risk for bone loss, but more human studies are needed to confidently observe benefits and determine the duration and extent of these changes.

Numerous mechanisms have been described to explain prebiotic effects on bone health. Colonic fermentation of prebiotics by organisms such as bifidobacteria [14] result in the release of SCFAs and subsequent drop in $\mathrm{pH}$. This SCFA-induced acidic environment, as well as GOS, lactulose, and inulin ingestion in general, are associated with enterocyte generation and improved colonic surface area, thus a greater capacity to absorb minerals [22,34,35]. Negatively-charged SCFAs also conjugate with $\mathrm{Ca}^{2+}$ ions to enhance passive diffusion through the lipid membrane of enterocytes, and their capacity to donate a proton can be used for exchange with luminal calcium through $\mathrm{H}^{+} / \mathrm{Ca}^{2+}$ antiporters [36,37]. These effects may become limited with age due to the decline of bifidobacteria numbers [38], perhaps correlating with reduced uptake of calcium and magnesium. Yet, it seems hard to imagine that a single bacterial genus plays such a pivotal role in skeletal strength, and the reason for its decline is unknown. It is more likely that a number of functionally redundant gastrointestinal bacteria must become reduced to impact bone density and health. Since there is little to suggest that intake of microbiome-stimulating fermented foods or fibres lowers in elder years, at least per a Korean study [39], dietary and drug intake patterns should be queried to try and understand how the microbiome changes with age to affect bone health. For example, proton pump inhibitors disproportionately used by older adults induce dysbiosis notably by a loss of bifidobacteria [40], 
but are only weakly associated with fractures and reduced bone density [41,42]. Other medications used predominantly by the older population such as diuretics [43] and glucocorticoids [44], used to treat water retention and inflammation respectively, are independent risk factors for osteoporosis and bone density loss [45].

Table 1. Summary of findings from human prebiotic interventions on bone health.

\begin{tabular}{|c|c|c|c|}
\hline Type of Trial & Prebiotic Used & Main Finding & Reference \\
\hline $\begin{array}{l}\text { Randomized, double-blind, } \\
\text { placebo-controlled crossover }\end{array}$ & $\begin{array}{l}\text { Inulin/oligofructose } \\
\operatorname{mix}(\text { Synergy1) }\end{array}$ & $\begin{array}{l}\text { Improved calcium and magnesium absorption } \\
\text { and bone turnover in postmenopausal women. }\end{array}$ & $\begin{array}{l}\text { Holloway et al., } \\
2007 \text { [23] }\end{array}$ \\
\hline $\begin{array}{l}\text { Randomized, double-blind, } \\
\text { placebo-controlled crossover }\end{array}$ & scFOS & $\begin{array}{l}\text { scFOS do not improve calcium absorption in } \\
\text { postmenopausal women. }\end{array}$ & Tahiri et al., 2003 [24] \\
\hline $\begin{array}{l}\text { Randomized, double-blind, } \\
\text { placebo-controlled }\end{array}$ & Chicory fructan & $\begin{array}{l}\text { Calcium absorption improved by chicory fructan } \\
\text { administration in postmenopausal women. }\end{array}$ & Kim et al., 2004 [25] \\
\hline $\begin{array}{l}\text { Randomized, double-blind, } \\
\text { placebo-controlled crossover }\end{array}$ & TOS & $\begin{array}{l}\text { Calcium absorption improved by TOS } \\
\text { administration in postmenopausal women. }\end{array}$ & $\begin{array}{l}\text { van den Heuvel et al., } \\
2000[26]\end{array}$ \\
\hline $\begin{array}{l}\text { Randomized, double-blind, } \\
\text { placebo-controlled crossover }\end{array}$ & Lactulose & $\begin{array}{l}\text { Calcium absorption improved by lactulose } \\
\text { administration in postmenopausal women. }\end{array}$ & $\begin{array}{l}\text { van den Heuvel et al., } \\
1999 \text { [27] }\end{array}$ \\
\hline $\begin{array}{l}\text { Randomized, double-blind, } \\
\text { placebo-controlled crossover }\end{array}$ & Inulin, FOS, and GOS & $\begin{array}{l}\text { Inulin, FOS, and GOS do not affect calcium or } \\
\text { iron absorption in healthy adult men. }\end{array}$ & $\begin{array}{l}\text { van den Heuvel et al., } \\
1998[28]\end{array}$ \\
\hline $\begin{array}{l}\text { Randomized, double-blind, } \\
\text { placebo-controlled }\end{array}$ & Inulin-type fructan & $\begin{array}{l}\text { Calcium absorption and bone content/density } \\
\text { improved by inulin-type fructan administration } \\
\text { in teenagers. }\end{array}$ & $\begin{array}{l}\text { Abrams et al., } \\
2005[29]\end{array}$ \\
\hline $\begin{array}{l}\text { Randomized, double-blind, } \\
\text { placebo-controlled crossover }\end{array}$ & $\begin{array}{l}\text { Oligofructose and } \\
\text { inulin/oligofructose mixture }\end{array}$ & $\begin{array}{l}\text { Calcium absorption improved by } \\
\text { inulin/oligofructose, but not oligofructose, } \\
\text { administration in adolescent girls. }\end{array}$ & $\begin{array}{l}\text { Griffin et al., } \\
2002[30]\end{array}$ \\
\hline $\begin{array}{l}\text { Randomized, double-blind, } \\
\text { placebo-controlled crossover }\end{array}$ & Oligofructose & $\begin{array}{l}\text { Calcium absorption improved by oligofructose } \\
\text { administration in adolescent boys. }\end{array}$ & $\begin{array}{l}\text { van den Heuvel et al., } \\
1999[31]\end{array}$ \\
\hline $\begin{array}{l}\text { Randomized, double-blind, } \\
\text { placebo-controlled }\end{array}$ & scFOS & $\begin{array}{l}\text { Bone turnover was minimized by scFOS } \\
\text { administration in postmenopausal women. } \\
\text { No effect on bone mineral density. }\end{array}$ & Slevin et al., 2014 [32] \\
\hline
\end{tabular}

\section{Prebiotics and the Brain}

The central nervous system and the gut, including its indigenous microbes, are bi-directionally linked by the "gut-brain axis", a network of distinct connections between these two major systems [46]. Several reviews have extensively covered the topic of microbiome effects on the brain [46-48], and concluded that three main pathways are involved-neural, endocrine, and immune. The major afferent neural pathway by which microbial products influence the brain is the vagus nerve, which directly innervates the gut [49]. Bravo and others [50] showed that the presence of certain gut microbes influences GABA receptor expression in the brain, and this link is lost by severing the vagus nerve. Prebiotics such as FOS and GOS, including the patented GOS produced by Bimuno (B-GOS), likely act through this connection to modulate neural growth factors like brain-derived neurotrophic factor, neurotransmitters such as d-serine, and synaptic proteins including synaptophysin and NMDA receptor subunits [51,52].

The primary neuroendocrine pathway affected by gut microbes is the hypothalamic-pituitary-adrenal (HPA) axis. This was determined by Sudo et al., who observed that normal microbiome development in mice is required for the induction of an appropriate stress response involving corticosterone and adrenocorticotropic hormone (ACTH) [53]. It is not surprising, then, that GOS and other prebiotics are able to modulate hormones such as plasma peptide YY [51]. Immune related effects also play an important role, but will be discussed in a later section. Together, studies on these systems have emphasized the necessity of gut microbes for the regulation of brain health. This has provided an avenue for prebiotics to manipulate neural processes, including cognitive ability, mood, and prevent certain psychological disorders through changes in microbiome activity and composition [48]. 


\subsection{Memory, Attention, and Learning}

Throughout our lifetime, memory and learning are crucial for mental health. This is especially apparent when we experience head trauma, Alzheimer's disease, or dementia, where these abilities are stunted. Many recent studies have linked the consumption of fermentable compounds to synaptic plasticity and memory, both in animal and human trials [54]. In rats, a polydextrose/GOS mixture and oligofructose-enriched inulin both improve memory by novel object recognition tasks or light extinction test [55,56]. A study by Sakai et al. [57] also demonstrated improved learning in rats administered sialyllactose and galactosylated $N$-acetylneuraminic acid. However, this may be specific to sialyllactose metabolism since its component sialic acid is known to enhance memory alone [58]. The story in humans is also consistently positive, as summarized in Table 2. Although administration of oligofructose-enriched inulin has no long-term benefits, possibly due to the numerous confounding factors in memory retention compounded over time, acute memory is significantly improved after a single $5 \mathrm{~g}$ dosage of oligofructose-enriched inulin [59,60]. A series of experiments on middle-aged adults by Best et al. [61,62] consistently demonstrated memory improvements due to various prebiotics. In two studies, Ambrotose complex, a mixture of arabinogalactan, aloe vera extract, and gum components, improved memory performance in the Rey Auditory Verbal Learning Test, even when controlling for blood glucose. Furthermore, regular dietary intake of foods containing indigestible carbohydrates such as rhamnose, xylose, and mannose may be sufficient to see improved memory aptitude, even if these effects are only self-perceived [63].

Due to the exceedingly promising results of these studies, it is important to determine how prebiotics could attenuate dementia and other conditions affecting memory. Using a mouse model of vascular dementia, Han et al. [64] demonstrated that arabinoxylan and arabinose improve general cognition, as measured by quicker completion of maze, and can limit dementia-related accumulation of glial fibrillary acidic protein. Other populations, such as preterm babies, also tend to be stunted in their memory and learning abilities due to underdevelopment. However, in a trial of 77 preterm infants, scGOS/lcFOS/pAOS had no effect on neural generation after two years [65]. Thus, prebiotics may be more effective in maintaining recall and learning rather than development.

\subsection{Mood and Anxiety}

A pioneering study equating the gut microbiome to mood and stress was performed by Sudo et al. [53]. They found that germ-free mice exposed to restraint stress had significantly elevated levels of circulating stress hormones $\mathrm{ACTH}$ and corticosterone, which were later shown to translate directly to anxiety-like behaviour [66,67]. Interestingly, normal ACTH and corticosterone levels could be restored by administering Bifidobacterium infantis to these otherwise sterile mice [53]. Given their bifidogenic properties, there is therefore sound basis for studying the stress-relieving potential of prebiotics.

Several animal models used in anxiety-related prebiotic trials have further clarified this connection. Administration of polydextrose and GOS to mice and male piglets was shown to reduce anxiety-related behaviour, and in rats, improve positive social interactions [56,68]. These effects may be partially attributable to structural changes in the development of the brain. For example, prebiotic-supplemented piglets have less gray matter compared to those fed a control diet, indicating an improvement in neural pruning [68]. This was also linked to beneficial intestinal enzymatic activity and modified gut microbiota [69]. There is still a lack of understanding of how these microbial changes and memory effects of prebiotics are connected, though some prebiotics have a well-defined action on stress responses because of known structure-specific effects. Digestion of $3^{\prime}$ and $6^{\prime}$ sialyllactose releases lactose and sialic acid, where the latter acts directly on the brain to improve memory and learning [58]. In further support of a prebiotic-independent effect of these compounds, Tarr and others [70] showed that mice fed sialyllactose had less anxiety in response to stressors without changes to the microbiome. However, without examining the metabolome, fermentation-induced changes to microbial activity cannot be ruled out. 
The current lack of human studies in this realm is partially a result of the complications and convoluting factors in studying behaviour and anxiety in humans, which have historically been avoided by directly measuring stress hormone levels. One group reported that daily consumption of $5.5 \mathrm{~g}$ of B-GOS by healthy individuals limited rapid elevations in salivary cortisol and improved attention upon exposure to a negative stimulus (Table 2) [71]. Further development in this field will require more human subjects, but considering the strong foundation by pioneering studies in animals, these appear to be promising. However, studies must be approached with particular caution due to newfound ethical concerns with manipulations of the microbiota. The observation that exploratory behaviour may be transferred with fecal transplants from normal to germ-free mice [72] emphasizes the importance of considering the psychological effects of altering gut microbes. While the intent of modulating the gut microbiota is to benefit people with brain and mental health ailments, one should be cautious in transferring personality traits between humans.

Table 2. Summary of findings from human prebiotic interventions on memory, attention, learning, and mood.

\begin{tabular}{llll}
\hline Type of Trial & Prebiotic Used & Main Finding & Reference \\
\hline Placebo-controlled crossover & Oligofructose/inulin mixture & $\begin{array}{l}\text { Oligofructose/inulin did not affect } \\
\text { fatigue, mood, reaction time, attention, } \\
\text { or memory after 43 days administration. }\end{array}$ & Smith, 2005 [59] \\
\hline $\begin{array}{l}\text { Randomized, double-blind, } \\
\text { placebo-controlled crossover }\end{array}$ & Oligofructose/inulin mixture & $\begin{array}{l}\text { Oligofructose/inulin improved mood, } \\
\text { recognition memory, and recall after 4 h. }\end{array}$ & Smith et al., 2015 [60] \\
\hline $\begin{array}{l}\text { Randomized, double-blind, } \\
\text { placebo-controlled }\end{array}$ & $\begin{array}{l}\text { Non-starch polysaccharides } \\
\text { (NSPs, Ambrotose complex) }\end{array}$ & $\begin{array}{l}\text { NSPs improved recall (RAVLT test) and } \\
\text { recognition memory and well-being in } \\
\text { middle-aged adults. }\end{array}$ & Best et al., 2009 [61] \\
\hline $\begin{array}{l}\text { Randomized, double-blind, } \\
\text { placebo-controlled, } \\
\text { between subjects }\end{array}$ & NSPs (Ambrotose complex) & $\begin{array}{l}\text { NSPs improved memory (RAVLT test) } \\
\text { acutely in middle-aged adults. }\end{array}$ & Best et al., 2015 [62] \\
\hline $\begin{array}{l}\text { Cross-sectional, } \\
\text { placebo-controlled }\end{array}$ & Dietary saccharides & $\begin{array}{l}\text { Saccharide intake improved self-reported } \\
\text { memory in middle-aged adults. }\end{array}$ & Best et al., 2009 [63] \\
\hline $\begin{array}{l}\text { Randomized, double-blind, } \\
\text { placebo-controlled }\end{array}$ & scGOS/lcFOS/pAOS mixture & $\begin{array}{l}\text { Prebiotic mixture did not improve } \\
\text { neurodevelopment in preterm infants. }\end{array}$ & $\begin{array}{l}\text { van den Berg et al., } \\
\text { 2016 [65] }\end{array}$ \\
\hline $\begin{array}{l}\text { Randomized, double-blind, } \\
\text { placebo-controlled }\end{array}$ & FOS and B-GOS & $\begin{array}{l}\text { B-GOS, but not FOS, reduced salivary } \\
\text { cortisol and improved attention in adults. }\end{array}$ & $\begin{array}{l}\text { Schmidt et al., } \\
\text { 2015 [71] }\end{array}$ \\
\hline
\end{tabular}

\subsection{Autism Spectrum Disorders}

One of the most apparent links between gastrointestinal and psychological health is in individuals with autism spectrum disorders (ASDs). Rates of gastrointestinal disorders in persons with ASDs have been reported to affect up to $70 \%$ compared to $9 \%$ of otherwise healthy individuals [73], with seriousness of gastrointestinal symptoms increasing with autism severity [74]. Gut microbes are an important factor contributing to digestive problems in individuals with ASDs, since the condition has been linked to a fecal microbiome with unusually high levels of Clostridium and depleted Bifidobacterium [74,75]. Several prebiotics including the wheat fiber Nutriose ${ }^{\circledR}$, among their benefits to colonic acidity, reduce Clostridium perfringens and enhance bifidobacteria [76], making prebiotics a promising therapeutic for ASD dysbiosis. The gut metabolome of children with autism also differs from healthy children, with characteristically reduced SCFAs [74]. Although probiotics have not successfully counteracted this depletion [74], the ability of prebiotics to stimulate SCFAs makes these products worthy of pursuit. However, the selection of prebiotics by their SCFA products becomes complicated by the recent implication of propionate and butyrate in autism pathogenesis. These SCFAs were found to increase the expression of tyrosine hydroxylase in a rat adrenal medulla cell line. This enzyme is responsible for producing catecholamines, a class of neurotransmitters whose levels are higher in individuals with ASDs [77]. It is not currently known if this study is translational to human subjects, but researchers selecting prebiotics for use on ASDs should consider compounds that avoid the production of these SCFAs. Ultimately, due to the lack of direct studies testing prebiotics in humans 
and the elusiveness of the condition, much more evidence is needed before conclusions can be made about prebiotic effects on ASDs. Furthermore, the finding that Bacteroides fragilis treatment of mice had no effect on microbiota richness, evenness, or relative class-level abundance, despite improving ASD behaviour [78], emphasizes the need to carefully analyse microbiome data [79] before selecting probiotic, prebiotic or synbiotic interventions. Understanding which prebiotics could stimulate specific SCFAs, excluding propionate and butyrate, might better target ASD therapy.

\subsection{Hepatic Encephalopathy}

Hepatic encephalopathy is a devastating mental condition brought about by failure of proper liver functioning. This causes rapid deterioration of a range of neural processes from movement and speech to cognition and personality, sometimes leading to coma and death if left untreated. Though its etiology is not entirely clear, serum ammonia levels are directly predictive of encephalopathy severity, and are considered the main enactor of neural degradation in the condition [80]. An incredible success in the treatment of hepatic encephalopathy occurred in 1966 with the introduction of prebiotic lactulose to manage gut ammonia [81]. Since its employment, lactulose has been widely regarded for its broad benefits to cognition and quality of life in encephalopathy patients [82]. Two recent meta-analyses of randomized human trials concluded that lactulose can effectively prevent and treat hepatic encephalopathy, and also improve underlying liver dysfunction [83,84].

Early studies recognized several probable mechanisms of lactulose's benefits on elevated blood ammonia. Fermentation of lactulose into fatty acids such as lactate reduces fecal $\mathrm{pH}$ by releasing protons into the colonic lumen. It was proposed that these protons convert ammonia into ammonium to create a concentration gradient that increases ammonia reuptake from blood into the gastrointestinal tract [85]. Concurrently, lactulose provides fermentable energy to colonic bacteria, diverting them from producing ammonia by amino acid metabolism, and can even directly inhibit glutaminases which degrade glutamine into ammonia [83]. Lastly, lactulose can flush out metabolites such as ammonia by shortening colonic transit time. Many of these properties are shared by a number of prebiotics - colonic acidification, fermentation, and stool softening - and have provided the basis for testing other indigestible saccharides for this purpose. In fact, a number of other compounds can also benefit hepatic encephalopathy, particularly lactitol [86]. Lactitol is equally as effective as lactulose in treating encephalopathy, and actually has fewer negative side effects such as diarrhea $[87,88]$. The success of using these prebiotics for treating a liver and brain related disorder further provides evidence for prebiotic compounds impacting distant sites.

\section{Immune Function}

It has been well documented that prebiotics can modulate immune functioning locally in Peyer's patches, but an increasing body of evidence suggests that these compounds also exert immunological benefits throughout the body. Although isolated immune systems are generally unaffected by prebiotics such as fructans $[89,90]$, clear benefits are observable in response to immune challenges. Since we are constantly exposed to a range of foreign stimuli, prebiotics could therefore be effective to downplay their effects. We will review here the immunomodulatory benefits of prebiotics in the context of challenges from pathogens, atopic dermatitis, and chronic inflammation, as well as their ability to improve mounted responses against vaccinations. Key human interventions studying prebiotic benefits on immune function will be summarized in Table 3.

The immunostimulatory properties of prebiotics can, in some cases, improve mounted memory development against vaccinations and pathogens. Oligofructose administered to infants several weeks leading up to measles vaccination elevates their measles-specific IgG response [91]. Even later in life, $\beta$-fructan prebiotics promote adaptive responses against influenza vaccination. In a study by Lomax et al. [92], four weeks of $8 \mathrm{~g}$ daily oligofructose/inulin mix prior to and following immunization was sufficient to increase circulating antibodies for influenza in a cohort of middle-aged adults. Unfortunately, this mounted immune response was limited to the $\mathrm{H}_{3} \mathrm{~N}_{2}$-like strain, despite 
the vaccine also containing $\mathrm{H}_{1} \mathrm{~N}_{1}$ - and B-like virus. A similarly selective response was seen in a cohort of elderly persons consuming a dietary supplement containing oligofructose/inulin and triacylglycerol, with antibodies mounted for $\mathrm{H}_{1} \mathrm{~N}_{1}$ - over $\mathrm{H}_{3} \mathrm{~N}_{2}$ - and B-like viruses [93]. It is currently unknown what properties of the prebiotics impart this selectivity, though if this were determined, prebiotic formulations could be manipulated to stimulate unique immune responses against immunized viruses. Prebiotics may also have general immune benefits when used alongside immunization. A unique oligosaccharide mixture (9:1 short-chain GOS to long-chain FOS + pAOS) fed to mice prior to vaccination improved their type IV hypersensitivity response, a form of cell-mediated immunity [94]. In turn, this immune response evoked enhanced skin induration and CD4+ T cell counts against toxins other than the vaccinated pathogen [95]. If this is observable in humans, an improvement in circulating antibodies and cell-mediated immunity by a food product would be beneficial especially to individuals at high risk for infection such as children and the elderly.

Prebiotics and probiotics have been extremely successful at suppressing indigestion and diarrhea due to pathogens. These conditions in infants are common and can be quite serious, particularly in the developing world [96]. For this reason, researchers have measured the effects of oligofructose on diarrhea-associated fever and required medical attention in infants $[97,98]$. They found that children with a similar occurrence of diarrhea experienced fewer episodes of fever, trips to the doctor, and antibiotic use while consuming $1 \mathrm{~g}$ /day oligofructose-supplemented cereal. Even though their ability to combat loose stool was unchanged, oligofructose may improve young children's ability to fight off underlying infection to reduce associated morbidities.

On the other end of the immune spectrum, excessive response to a foreign stimulus can lead to allergic diseases such as asthma, atopic dermatitis, and eczema. A meta-analysis of human clinical trials for allergic diseases in children concluded that prebiotics are protective against the onset of eczema, with a potential trend for combatting allergic diseases [99]. For example, infants fed formula supplemented with a GOS/FOS/pAOS mixture for 6-10 months had a 44\% lower prevalence of atopic dermatitis and a low risk for developing the condition [100], as did another formula containing a GOS/FOS mixture [101]. Contrary to this, a more recent study used partially hydrolyzed formula supplemented with the same GOS/FOS prebiotic and found no effect on eczema prevalence [102]. However, partially hydrolyzed formula components such as whey protein can minimize allergic skin reactions alone, and this may have masked the effects of prebiotic supplementation [103]. Even naturally occurring human milk oligosaccharides found in women expressing the sugar secretory protein FUT2 are associated with fewer cases of allergic disease and eczema in their breast-fed children [104]. This is partially due to fructan's inhibitory effect on IgE expression, such as what was observed in a synbiotic trial by Kukkonen and group [105]. Others postulate that galectin-9 may be upregulated by milk oligosaccharides to induce $\mathrm{T}$ cell differentiation selectively into Th1- and regulatory $\mathrm{T}$ cells, which mitigate excessive inflammation [106]. Support for this hypothesis also comes from the fact that depletion of CD25+ regulatory $\mathrm{T}$ cells reverses the beneficial effects of scGOS/lcFOS/pAOS treatment on atopic dermatitis in mice [107]. Both of these direct and indirect mechanisms are likely involved in the action of milk oligosaccharides on suppressing excessive immune responses.

Though there are few human trials for the use of prebiotics to prevent allergic diseases other than atopic dermatitis, support can be found from animal studies. In an ovalbumin (OVA)-induced mouse model for allergic asthma, scGOS/lcFOS reduces symptoms including bronchial inflammation, skin lesions and lung resistance, probably through a reduction in IgE and increased OVA-specific IgG and regulatory $\mathrm{T}$ cells in serum [108,109]. Unfortunately a small proportion $(0 \%-3.5 \%)$ of the population is allergic to GOS, though this is dependent on the particular formulation [110]. More research will be needed to take these promising results into clinical testing and select a prebiotic with the least allergic properties, particularly in children at risk for developing allergic asthma.

While there is a clear link between inflammation and allergic diseases, long-term inflammation more subtly contributes to a number of chronic problems such as cancer, cardiovascular, and lung 
diseases. There is, therefore, a growing interest in modulating immune responses to decrease long-term inflammation. Elderly people, who are generally most affected by the comorbidities of chronic inflammation, also commonly experience gut dysbiosis with a decreased proportion of bifidobacteria [111]. A number of studies have shown that prebiotics can benefit the elderly by improving their gut microbiota and immune function, ultimately reducing inflammation. An $8 \mathrm{~g}$ daily oligofructose/inulin mixture given for three weeks to the elderly reduced expression of pro-inflammatory IL-6 by peripheral blood mononuclear cells (PBMCs) and improved T cell counts [112]. Others have observed that B-GOS (5.5 g daily for 10 weeks) lowers circulating levels of inflammatory cytokines such as IL-6, IL-1 $\beta$, and TNF- $\alpha$, and raises immunomodulatory IL-10 [113,114]. Furthermore, B-GOS stimulates natural killer T cells, potentially improving antiviral activity [113].

Distant effects of prebiotics on the immune system are likely mediated by fermentation products of gut bacteria that pass through enterocytes to tissue and circulating immune cells, or in rare cases, direct binding of prebiotics to immune cells. As an example, SCFAs, especially butyrate, derived from microbial degradation of inulin, hi-maize and $\beta$-glucan can reduce production of IFN- $\gamma$, IL-12, TNF- $\alpha$, and TGF- $\beta 1$, and elevate IL-4 and IL-10 release from lipopolysaccharide-stimulated PBMCs [115]. It has been postulated that IL-10 acts as an overarching mediator of anti-inflammatory effects on a range of cytokines. This is not the complete story for all prebiotics, since soluble dextrins can reduce proinflammatory cytokines even in the absence of IL-10 [116], however in most cases, IL-10 is elevated following prebiotic administration. Alternatively, some indigestible carbohydrates may actually permeate through the colonic barrier and act on immune cells by binding sugar-specific receptors. The well-characterized dectin-1, a monocyte and macrophage receptor protein, has particular affinity for $\beta$-glucan prebiotics $[117,118]$. Binding of $\beta$-glucan activates this receptor to adhere to pathogenic Candida albicans and induce phagocytosis, thereby improving antimicrobial properties in the liver, lung, and thymus, where this receptor is highly expressed [117].

The key to future studies will be fully characterizing the distinct mechanisms employed by different prebiotics to balance immune responses, particularly due to the broad range of modulatory activities they exert. For this reason, prebiotics are an exciting therapy for counteracting dysregulation of the immune system linked to the microbiome.

Table 3. Summary of findings from human prebiotic interventions on immune function.

\begin{tabular}{|c|c|c|c|}
\hline Type of Trial & Prebiotic Used & Main Finding & Reference \\
\hline $\begin{array}{l}\text { Randomized, double-blind, } \\
\text { placebo-controlled, crossover }\end{array}$ & $\beta 2-1$ fructans & $\begin{array}{l}\beta 2-1 \text { fructans increased blood IL-4, } \\
\text { CD282+/TLR2+ myeloid dendritic } \\
\text { cells, and a TLR2-mediated immune } \\
\text { response in healthy adults. }\end{array}$ & Clarke et al., 2016 [89] \\
\hline $\begin{array}{l}\text { Randomized, double-blind, } \\
\text { placebo-controlled }\end{array}$ & $\beta 2-1$ fructans & $\begin{array}{l}\beta 2-1 \text { fructans did not affect numbers } \\
\text { of blood immune cells or Ig, salivary } \\
\text { IgA, or immune activity in } \\
\text { healthy adults. }\end{array}$ & Lomax et al., 2012 [90] \\
\hline $\begin{array}{l}\text { Randomized, double-blind, } \\
\text { placebo-controlled }\end{array}$ & Oligofructose/inulin mixture & $\begin{array}{l}\text { Oligofructose/inulin improved } \\
\text { antibody response to } \\
\text { measles vaccination }\end{array}$ & $\begin{array}{l}\text { Firmansyah et al., } \\
2001 \text { [91] }\end{array}$ \\
\hline $\begin{array}{l}\text { Randomized, double-blind, } \\
\text { placebo-controlled }\end{array}$ & Oligofructose/inulin mixture & $\begin{array}{l}\text { Oligofructose/inulin increased } \\
\text { circulating influenza-specific } \\
\text { antibodies after vaccination in } \\
\text { healthy adults. }\end{array}$ & Lomax et al., 2015 [92] \\
\hline $\begin{array}{l}\text { Randomized, double-blind, } \\
\text { placebo-controlled }\end{array}$ & Oligofructose-supplemented cereal & $\begin{array}{l}\text { Prebiotic cereal reduced } \\
\text { diarrhea-associated fever and } \\
\text { medical attention in infants. }\end{array}$ & Saavedra et al., 1999 [97] \\
\hline $\begin{array}{l}\text { Randomized, double-blind, } \\
\text { placebo-controlled }\end{array}$ & Oligofructose-supplemented cereal & $\begin{array}{l}\text { Prebiotic cereal reduced sick days, } \\
\text { antibiotic use and febrile seizures } \\
\text { in infants. }\end{array}$ & Tschernia et al., 1999 [98] \\
\hline
\end{tabular}


Table 3. Cont.

\begin{tabular}{|c|c|c|c|}
\hline Type of Trial & Prebiotic Used & Main Finding & Reference \\
\hline $\begin{array}{l}\text { Randomized, double-blind, } \\
\text { placebo-controlled, prospective }\end{array}$ & scGOS/lcFOS/pAOS & $\begin{array}{l}\text { scGOS } / \mathrm{lcFOS} / \mathrm{pAOS} \text { reduced the } \\
\text { development rate of atopic } \\
\text { dermatitis in low-risk infants. }\end{array}$ & Grüber et al., 2010 [100] \\
\hline $\begin{array}{l}\text { Randomized, double-blind, } \\
\text { placebo-controlled, prospective }\end{array}$ & GOS/FOS & $\begin{array}{l}\text { GOS/FOS reduced the development } \\
\text { rate of atopic dermatitis in } \\
\text { high-risk infants. }\end{array}$ & Moro et al., 2006 [101] \\
\hline $\begin{array}{l}\text { Randomized, double-blind, } \\
\text { placebo-controlled, parallel-group }\end{array}$ & Partially hydrolyzed FOS & $\begin{array}{l}\text { FOS reduced antibodies against } \\
\text { cow's milk and increased circulating } \\
\text { Treg and plasmacytoid dendritic } \\
\text { cells, but did not prevent the } \\
\text { development of eczema in infants. }\end{array}$ & Boyle et al., 2016 [102] \\
\hline Cross-sectional & $\begin{array}{l}\text { FUT2-dependent breast milk } \\
\text { oligo-saccharides }\end{array}$ & $\begin{array}{l}\text { FUT2-dependent breast milk } \\
\text { oligosaccharides are associated with } \\
\text { reduced risk for allergic disease in } \\
\text { high-risk infants. }\end{array}$ & $\begin{array}{l}\text { Sprenger et al., } \\
2016[104]\end{array}$ \\
\hline $\begin{array}{l}\text { Randomized, double-blind, } \\
\text { placebo-controlled }\end{array}$ & Probiotic supplement with GOS & $\begin{array}{l}\text { Probiotic/prebiotic mixture reduced } \\
\text { the occurrence of eczema in } \\
\text { high-risk infants. }\end{array}$ & $\begin{array}{l}\text { Kukkonen et al., } \\
2007 \text { [105] }\end{array}$ \\
\hline Pretest-posttest & FOS & $\begin{array}{l}\text { FOS decreased inflammatory IL- } 6 \\
\text { expression and phagocytosis } \\
\text { activity by granulocytes and } \\
\text { monocytes in elderly people. }\end{array}$ & Guigoz et al., 2002 [112] \\
\hline $\begin{array}{l}\text { Randomized, double-blind, } \\
\text { placebo-controlled, crossover }\end{array}$ & B-GOS & $\begin{array}{l}\text { B-GOS increased phagocytosis and } \\
\text { NK cell activity while promoting } \\
\text { an anti-inflammatory cytokine } \\
\text { profile in elderly people. }\end{array}$ & Vulevic et al., 2008 [113] \\
\hline $\begin{array}{l}\text { Randomized, double-blind, } \\
\text { placebo-controlled, crossover }\end{array}$ & B-GOS & $\begin{array}{l}\text { B-GOS increased NK cell activity } \\
\text { and circulating IL-10, IL- } 8 \text {, } \\
\text { and C-reactive protein, while } \\
\text { reducing IL-1 } \beta \text {, in elderly people. }\end{array}$ & Vulevic et al., 2015 [114] \\
\hline
\end{tabular}

\section{Dermatological Health}

New and upcoming applications of prebiotics have emerged for a variety of skin-related conditions. This was first recognized by researchers' observations that prebiotics can attenuate allergic-related skin diseases such as atopic dermatitis, as discussed in the previous section. However, a few other studies have shown alternative benefits to dermatological health. In particular, UV radiation is damaging to the skin, leading to erythema and sometimes cancer. In hairless mice, a model for human skin, 12 weeks of GOS supplementation improved water retention and prevented erythema [119]. Furthermore, GOS treatment increased dermal expression of cell adhesion and matrix formation markers CD44, TIMP-1, and type 1 collagen, thereby improving the skin's barrier properties. Even in the absence of UV radiation, hydration and keratinization are critical for healthy skin. In women, GOS alone or with probiotic Bifidobacterium breve can prevent water and keratin depletion caused by phenolic compounds [120]. Phenols such as p-cresol are normally produced by gut microbes as a by-product of aromatic amino acid metabolism, which can be absorbed and transported into the skin [121] and are toxic in cases of renal failure [122]. The beneficial effects of GOS on skin character could therefore be attributable to their ability to divert enteric microbes from amino acid metabolism and production of damaging phenols by providing an alternative food source.

\section{Cardiovascular Health}

In 2013, approximately $30 \%$ of deaths in the US were a result of cardiovascular disease, including stroke and heart failure [123]. The major contributors to this alarming statistic are poor nutrition and the rise in severe obesity, particularly in the young population [123]. A diet high in fat and low in fiber is increasingly popular in the developed world, and has therefore enticed researchers to evaluate how eating habits, and food-grade compounds such as prebiotics, can be utilized to reduce cardiovascular risk and other obesity-related comorbidities. As described earlier, a component of this is the ability of prebiotics to alleviate chronic inflammation thereby lowering the risk for developing cardiovascular 
disease. Although direct influence of prebiotic intake on cardiovascular health has not been shown, a number of studies have associated indigestible fiber intake with improved serum lipid profiles, as summarized in Table 4. Targets for this therapy are to reduce blood triacylglycerol (TAG) and low density lipoprotein (LDL) cholesterol, and elevate high density lipoprotein (HDL) cholesterol that become imbalanced in heart disease. Thus prebiotics that improve the equilibrium of these fats may be beneficial as part of an effective nutritional intervention to combat cardiovascular risk.

The vast majority of human lipid profile and prebiotic studies have utilized fructooligosaccharide compositions containing oligofructose and inulin, but the results have been contentious. Letexier et al. [124] observed a reduction in serum TAG and lipogenesis in the liver of healthy adults with a three-week regimen of $10 \mathrm{~g}$ / day inulin. Yet a nearly identical study by Forcheron and Beylot [125] saw no significant changes to lipid profile or synthesis in a larger cohort, despite a much longer 6 month intervention. This might be because an inulin-oligofructose mixture, rather than pure inulin, was used, however oligofructose requires the same enzymes for microbial metabolism and should therefore have similar effects on the microbiome. In another study, the potential benefits of inulin on plasma TAG, HDL, and lipoprotein(a) were confounded by the administration of a regulated carbohydrate-rich, low-fat diet. Compared to baseline, inulin-supplemented diet balanced the lipid profile, but following the interventions, no significant differences were observed between inulin and placebo diet except for a reduction in the total cholesterol/HDL ratio [126]. This underlines the importance of controlling for other factors such as diet in prebiotic research. A meta-analysis of human clinical trials between 1995 and 2005 identified the TAG-reducing properties of fructooligosaccharides, with a $7.5 \%$ average decrease in serum [127]. The author admitted that this was a minimal reduction compared to current drug therapies, and that only 5 out of 16 studies actually reached significance. Since this meta-analysis, several other studies have corroborated this trend where TAGs are significantly lowered by a small proportion of interventions, enough to cause a mean effect [128]. It could be that large reductions in TAG are observed in some cases and no change in others because of differences in the initial concentration of these fats in the population studied. Presumably larger decreases would be observed in individuals with initially high levels of TAG.

To a lesser extent, a number of other prebiotic compounds have had positive effects on serum lipids. High dosages ( $25 \mathrm{~g} /$ day) of L-rhamnose and lactulose have been shown to minimize both the synthesis and serum concentration of TAG [129]. This is in contrast to results from another study observing that lactulose elevates circulating cholesterol by $10 \%$ and apolipoprotein B by $19 \%$, potentially negating its beneficial effects [130]. In overweight subjects, a 12-week treatment of $5.5 \mathrm{~g} / \mathrm{day}$ B-GOS reduced serum triglycerides and total:HDL cholesterol ratio and modulated circulating insulin, though the effect was far more pronounced in men than women [131]. The benefits of B-GOS on plasma lipids is likely limited to individuals with hypercholesterolemia, since identical dosage to healthy elderly adults saw no effect on total or HDL cholesterol [113]. A more generalizable effect has been observed with consumption of $\beta$-glucan prebiotics. A recent meta-analysis of $126 \beta$-glucan studies concluded that total and LDL cholesterol are slightly reduced, an average of $0.60 \mathrm{mmol} / \mathrm{L}$ and $0.66 \mathrm{mmol} / \mathrm{L}$ respectively, given at least $2 \mathrm{~g}$ daily supplementation [132].

An important consideration with these interventions is that, although each prebiotic was bifidogenic, there was a large variability between compounds on which serum lipids were modulated upon treatment and to what extent. Several researchers have proposed that the profile of SCFAs produced by gut fermentation of each prebiotic directs its effect on lipid synthesis and circulating concentrations. For example, absorbed acetate is converted to acetyl-CoA where it acts as a substrate for fatty acid synthesis in hepatocytes [133], explaining why cholesterol and triglycerides in blood are increased by rectally infused acetate [134]. Thus, predominantly acetate-producing substrates such as lactulose [135] and GOS [6] may have a negative effect on lipids when ingested. Fructooligosaccharides tend to produce relatively equal proportions of acetate and butyrate, potentially balancing this effect [6]. Interestingly, propionate prevents acetate-induced lipid synthesis [136], suggesting that propionate producers such as L-rhamnose and fructooligosaccharides could balance the lipogenic effects of 
acetate $[6,135]$. Careful selection of prebiotics by their acid metabolites for management of cholesterol and other serum lipids is ultimately of utmost importance to obtain optimal results.

With the success of certain prebiotics in balancing the serum lipid profile and promoting satiety, these fermentable sugars may also benefit other obesity-associated comorbidities. For this reason, prebiotics have been proposed as a treatment for fatty liver disease, despite there being insufficient human trials utilizing only prebiotics to support this claim [137]. An ongoing randomized, placebo-controlled trial will help elucidate mechanistic links and potential benefits of administering an oligofructose-inulin mixture to NAFLD patients [138]. Regardless, this is a currently untouched avenue for prebiotic research and warrants further investigation of fermentation-related effects on cholesterol and obesity-related diseases.

Table 4. Summary of findings from human prebiotic interventions on serum lipid profile.

\begin{tabular}{|c|c|c|c|}
\hline Type of Trial & Prebiotic Used & Main Finding & Reference \\
\hline $\begin{array}{l}\text { Randomized, double-blind, } \\
\text { placebo-controlled crossover }\end{array}$ & Inulin & $\begin{array}{l}\text { Inulin reduced blood triacylglycerol and } \\
\text { lipogenesis, but did not affect cholesterol } \\
\text { in healthy people. }\end{array}$ & $\begin{array}{l}\text { Letexier et al., } \\
2003[124]\end{array}$ \\
\hline $\begin{array}{l}\text { Randomized, double-blind, } \\
\text { placebo-controlled }\end{array}$ & Inulin/oligofructose mixture & $\begin{array}{l}\text { Inulin/oligofructose had no effect on } \\
\text { plasma lipid profile over } 6 \text { months in } \\
\text { healthy people. }\end{array}$ & $\begin{array}{l}\text { Forcheron and } \\
\text { Beylot, 2007 [125] }\end{array}$ \\
\hline Partially randomized crossover & Lactulose and L-rhamnose & $\begin{array}{l}\text { Lactulose and L-rhamnose both reduced } \\
\text { triacylglycerol levels and synthesis in } \\
\text { healthy men. Cholesterol was unaffected. }\end{array}$ & $\begin{array}{l}\text { Vogt et al., } \\
2006 \text { [129] }\end{array}$ \\
\hline $\begin{array}{l}\text { Randomized, double-blind, } \\
\text { placebo-controlled crossover }\end{array}$ & B-GOS & $\begin{array}{l}\text { B-GOS reduced serum cholesterol, } \\
\text { triacylglycerol and total:HDL cholesterol } \\
\text { ratio in overweight people. }\end{array}$ & $\begin{array}{l}\text { Vulevic et al., } \\
2013[131]\end{array}$ \\
\hline
\end{tabular}

\section{Conclusions}

A great deal of research supports the use of prebiotic compounds for a range of positive health outcomes distant to the gut, particularly for improved bone density, anxiety, hyperammonemia, and blood lipid profile. However, what the current studies lack are a distinct mechanistic link between the metabolism or binding of these compounds and the effects they induce. In some cases, there is a clear, observable connection, such as the ammonia-reducing effects of disaccharides in hepatic encephalopathy patients, but this is relatively rare. More human clinical trials are needed, particularly longitudinal, that have the power to observe subtle changes over the duration of ingestion, as well as carefully controlled animal studies to explain how these effects occur. Given the success of prebiotics in the attenuation of many diseases and improvement of health at distant sites, these food-grade saccharides are becoming key components of a health-promoting diet.

Acknowledgments: This research received no specific grant from any funding agency in the public, commercial, or not-for-profit sectors.

Author Contributions: This review was written by Stephanie Collins and Gregor Reid.

Conflicts of Interest: The authors declare no conflict of interest.

\section{References}

1. Turroni, F.; Ventura, M.; Buttó, L.F.; Duranti, S.; O’Toole, P.W.; Motherway, M.O.; van Sinderen, D. Molecular dialogue between the human gut microbiota and the host: A Lactobacillus and Bifidobacterium perspective. Cell. Mol. Life Sci. 2014, 71, 183-203. [CrossRef] [PubMed]

2. Gibson, G.R.; Roberfroid, M.B. Dietary modulation of the human colonic microbiota: Introducing the concept of prebiotics. J. Nutr. 1995, 125, 1401-1412. [PubMed] 
3. Gibson, G.R.; Probert, H.M.; Loo, J.V.; Rastall, R.A.; Roberfroid, M.B. Dietary modulation of the human colonic microbiota: Updating the concept of prebiotics. Nutr. Res. Rev. 2004, 17, 259-275. [CrossRef] [PubMed]

4. Patel, S.; Goyal, A. Functional oligosaccharides: Production, properties and applications. World J. Microbiol. Biotechnol. 2011, 27, 1119-1128. [CrossRef]

5. Roberfroid, M.B. Health benefits of non-digestible oligosaccharides. Adv. Exp. Med. Biol. 1997, 427, $211-219$. [PubMed]

6. Hernot, D.C.; Boileau, T.W.; Bauer, L.L.; Middelbos, I.S.; Murphy, M.R.; Swanson, K.S.; Fahey, G.C. In vitro fermentation profiles, gas production rates, and microbiota modulation as affected by certain fructans, galactooligosaccharides, and polydextrose. J. Agric. Food Chem. 2009, 57, 1354-1361. [CrossRef] [PubMed]

7. Zhou, Z.; Zhang, Y.; Zheng, P.; Chen, X.; Yang, Y. Starch structure modulates metabolic activity and gut microbiota profile. Anaerobe 2013, 24, 71-78. [CrossRef] [PubMed]

8. Ríos-Covián, D.; Ruas-Madiedo, P.; Margolles, A.; Gueimonde, M.; de los Reyes-Gavilán, C.G.; Salazar, N. Intestinal short chain fatty acids and their link with diet and human health. Microb. Physiol. Metab. 2016, 7, 185. [CrossRef] [PubMed]

9. Hamer, H.M.; Jonkers, D.; Venema, K.; Vanhoutvin, S.; Troost, F.J.; Brummer, R.J. Review article: The role of butyrate on colonic function. Aliment. Pharmacol. Ther. 2008, 27, 104-119. [CrossRef] [PubMed]

10. Den Besten, G.; van Eunen, K.; Groen, A.K.; Venema, K.; Reijngoud, D.J.; Bakker, B.M. The role of short-chain fatty acids in the interplay between diet, gut microbiota, and host energy metabolism. J. Lipid Res. 2013, 54, 2325-2340. [CrossRef] [PubMed]

11. Eiwegger, T.; Stahl, B.; Haidl, P.; Schmitt, J.; Boehm, G.; Dehlink, E.; Urbanek, R.; Szépfalusi, Z. Prebiotic oligosaccharides: In vitro evidence for gastrointestinal epithelial transfer and immunomodulatory properties. Pediatr. Allergy Immunol. 2010, 21, 1179-1188. [CrossRef] [PubMed]

12. Kanis, J.A. On behalf of the World Health Organization Scientific Group. In Assessment of Osteoporosis at the Primary Health-Care Level; Technical Report by the World Health Organization Collaborating Centre for Metabolic Bone Diseases; University of Sheffield: Sheffield, UK, 2007; p. 337.

13. Chonan, O.; Watanuki, M. Effect of galactooligosaccharides on calcium absorption in rats. J. Nutr. Sci. Vitaminol. 1995, 41, 95-104. [CrossRef] [PubMed]

14. Weaver, C.M.; Martin, B.R.; Nakatsu, C.H.; Armstrong, A.P.; Clavijo, A.; McCabe, L.D.; McCabe, G.P.; Duignan, S.; Schoterman, M.H.; van den Heuvel, E.G. Galactooligosaccharides improve mineral absorption and bone properties in growing rats through gut fermentation. J. Agric. Food Chem. 2011, 59, 6501-6510. [CrossRef] [PubMed]

15. Legette, L.L.; Lee, W.; Martin, B.R.; Story, J.A.; Campbell, J.K.; Weaver, C.M. Prebiotics enhance magnesium absorption and inulin-based fibers exert chronic effects on calcium utilization in a postmenopausal rodent model. J. Food Sci. 2012, 77, 88-94. [CrossRef] [PubMed]

16. Zafar, T.A.; Weaver, C.M.; Zhao, Y.; Martin, B.R.; Wastney, M.E. Nondigestible oligosaccharides increase calcium absorption and suppress bone resorption in ovariectomized rats. J. Nutr. 2004, 134, 399-402. [PubMed]

17. Chonan, O.; Matsumoto, K.; Watanuki, M. Effect of galactooligosaccharides on calcium absorption and preventing bone loss in ovariectomized rats. Biosci. Biotechnol. Biochem. 1995, 59, 236-239. [CrossRef] [PubMed]

18. Mitamura, R.; Hara, H. Prolonged feeding of difructose anhydride III increases strength and mineral concentrations of the femur in ovariectomized rats. Br. J. Nutr. 2005, 94, 268-274. [CrossRef] [PubMed]

19. Mitamura, R.; Hara, H.; Aoyama, Y.; Chiji, H. Supplemental feeding of difructose anhydride III restores calcium absorption impaired by ovariectomy in rats. J. Nutr. 2002, 132, 3387-3393. [PubMed]

20. Coxam, V. Current data with inulin-type fructans and calcium, targeting bone health in adults. J. Nutr. 2007, 137, 2527S-2533S. [PubMed]

21. McCabe, L.; Britton, R.A.; Parameswaran, N. Prebiotic and probiotic regulation of bone health: Role of the intestine and its microbiome. Curr. Osteoporos. Rep. 2015, 13, 363-371. [CrossRef] [PubMed]

22. Scholz-Ahrens, K.E.; Ade, P.; Marten, B.; Weber, P.; Timm, W.; Açil, Y.; Glüer, C.C.; Schrezenmeir, J. Prebiotics, probiotics, and synbiotics affect mineral absorption, bone mineral content, and bone structure. J. Nutr. 2007, 137, 838S-846S. [PubMed] 
23. Holloway, L.; Moynihan, S.; Abrams, S.A.; Kent, K.; Hsu, A.R.; Friedlander, A.L. Effects of oligofructose-enriched inulin on intestinal absorption of calcium and magnesium and bone turnover markers in postmenopausal women. Br. J. Nutr. 2007, 97, 365-372. [CrossRef] [PubMed]

24. Tahiri, M.; Tressol, J.C.; Arnaud, J.; Bornet, F.R.; Bouteloup-Demange, C.; Feillet-Coudray, C.; Brandolini, M.; Ducros, V.; Pépin, D.; Brouns, F.; et al. Effect of short-chain fructooligosaccharides on intestinal calcium absorption and calcium status in postmenopausal women: A stable-isotope study. Am. J. Clin. Nutr. 2003, 77, 449-457. [PubMed]

25. Kim, Y.Y.; Jang, K.H.; Kang, S.A.; Ha, W.K.; Lee, E.Y.; Cho, Y.H.; Choue, R.W. The effect of chicory fructan fiber on calcium absorption and bone metabolism in Korean postmenopausal women. Nutr. Sci. 2004, 7, 151-157.

26. Van den Heuvel, E.G.; Schoterman, M.H.; Muijs, T. Transgalactooligosaccharides stimulate calcium absorption in postmenopausal women. J. Nutr. 2000, 130, 2938-2942. [PubMed]

27. Van den Heuvel, E.G.; Muijs, T.; van Dokkum, W.; Schaafsma, G. Lactulose stimulates calcium absorption in postmenopausal women. J. Bone Miner. Res. 1999, 14, 1211-1216. [CrossRef] [PubMed]

28. Van den Heuvel, E.G.; Schaafsma, G.; Muys, T.; van Dokkum, W. Nondigestible oligosaccharides do not interfere with calcium and nonheme-iron absorption in young, healthy men. Am. J. Clin. Nutr. 1998, 67, 445-451. [PubMed]

29. Abrams, S.A.; Griffin, I.J.; Hawthorne, K.M.; Liang, L.; Gunn, S.K.; Darlington, G.; Ellis, K.J. A combination of prebiotic short- and long-chain inulin-type fructans enhances calcium absorption and bone mineralization in young adolescents. Am. J. Clin. Nutr. 2005, 82, 471-476. [PubMed]

30. Griffin, I.J.; Davila, P.M.; Abrams, S.A. Non-digestible oligosaccharides and calcium absorption in girls with adequate calcium intakes. Br. J. Nutr. 2002, 87, S187-S191. [CrossRef] [PubMed]

31. Van den Heuvel, E.G.; Muys, T.; van Dokkum, W.; Schaafsma, G. Oligofructose stimulates calcium absorption in adolescents. Am. J. Clin. Nutr. 1999, 69, 544-548. [PubMed]

32. Slevin, M.M.; Allsopp, P.J.; Magee, P.J.; Bonham, M.P.; Naughton, V.R.; Strain, J.J.; Duffy, M.E.; Wallace, J.M.; Mc Sorley, E.M. Supplementation with calcium and short-chain fructo-oligosaccharides affects markers of bone turnover but not bone mineral density in postmenopausal women. J. Nutr. 2014, 144, 297-304. [CrossRef] [PubMed]

33. Reid, G.; Younes, J.A.; Van der Mei, H.C.; Gloor, G.B.; Knight, R.; Busscher, H.J. Microbiota restoration: Natural and supplemented recovery of human microbial communities. Nat. Rev. Microbiol. 2011, 9, 27-38. [CrossRef] [PubMed]

34. Pérez-Conesa, D.; López, G.; Ros, G. Effects of probiotic, prebiotic and synbiotic follow-up infant formulas on large intestine morphology and bone mineralisation in rats. J. Sci. Food Agric. 2007, 87, 1059-1068. [CrossRef]

35. Zduńczyk, Z.; Juśkiewicz, J.; Wróblewska, M.; Król, B. Physiological effects of lactulose and inulin in the caecum of rats. Arch. Anim. Nutr. 2004, 58, 89-98. [CrossRef] [PubMed]

36. Trinidad, T.P.; Wolever, T.M.; Thompson, L.U. Effect of acetate and propionate on calcium absorption from the rectum and distal colon of humans. Am. J. Clin. Nutr. 1996, 63, 574-578. [PubMed]

37. Trinidad, T.P.; Wolever, T.M.; Thompson, L.U. Effects of calcium concentration, acetate, and propionate on calcium absorption in the human distal colon. Nutrition 1999, 15, 529-533. [CrossRef]

38. Mitsuoka, T. Intestinal flora and aging. Nutr. Rev. 1992, 50, 438-446. [PubMed]

39. Kim, E.K.; Ha, A.W.; Choi, E.O.; Ju, S.Y. Analysis of Kimchi, vegetable and fruit consumption trends among Korean adults: Data from the Korea National Health and Nutrition Examination Survey (1998-2012). Nutr. Res. Pract. 2016, 10, 188-197. [CrossRef] [PubMed]

40. Imhann, F.; Bonder, M.J.; Vila, A.V.; Fu, J.; Mujagic, Z.; Vork, L.; Tigchelaar, E.F.; Jankipersadsing, S.A.; Cenit, M.C.; Harmsen, H.J.; et al. Proton pump inhibitors affect the gut microbiome. Gut 2016, 65, 740-748. [CrossRef] [PubMed]

41. Leontiadis, G.I.; Moayyedi, P. Proton pump inhibitors and risk of bone fractures. Curr. Treat. Options Gastroenterol. 2014, 12, 414-423. [CrossRef] [PubMed]

42. Ozdil, K.; Kahraman, R.; Sahin, A.; Calhan, T.; Gozden, E.H.; Akyuz, U.; Erer, B.; Sokmen, M.H. Bone density in proton pump inhibitors users: A prospective study. Rheumatol. Int. 2013, 33, 2255-2260. [CrossRef] [PubMed] 
43. Van Kraaij, D.J.; Jansen, R.W.; Gribnau, F.W.; Hoefnagels, W.H. Loop diuretics in patients aged 75 years or older: General practitioners' assessment of indications and possibilities for withdrawal. Eur. J. Clin. Pharmacol. 1998, 54, 323-327. [CrossRef] [PubMed]

44. Overman, R.A.; Yeh, J.Y.; Deal, C.L. Prevalence of oral glucocorticoid usage in the United States: A general population perspective. Arthritis Care Res. 2013, 65, 294-298. [CrossRef] [PubMed]

45. Holm, J.P.; Hyldstrup, L.; Jensen, J.B. Time trends in osteoporosis risk factor profiles: A comparative analysis of risk factors, comorbidities, and medications over twelve years. Endocrine 2016. [CrossRef] [PubMed]

46. Gaman, A.; Kuo, B. Neuromodulatory processes of the brain-gut axis. Neuromodulation 2008, 11, $249-259$. [CrossRef] [PubMed]

47. Grenham, S.; Clarke, G.; Cryan, J.F.; Dinan, T.G. Brain-gut-microbe communication in health and disease. Gastrointest. Sci. 2011, 2, 94. [CrossRef] [PubMed]

48. Liu, X.; Cao, S.; Zhang, X. Modulation of gut microbiota-brain axis by probiotics, prebiotics, and diet. J. Agric. Food Chem. 2015, 63, 7885-7895. [CrossRef] [PubMed]

49. Forsythe, P.; Bienenstock, J.; Kunze, W.A. Vagal pathways for microbiome-brain-gut axis communication. Adv. Exp. Med. Biol. 2014, 817, 115-133. [PubMed]

50. Bravo, J.A.; Forsythe, P.; Chew, M.V.; Escaravage, E.; Savignac, H.M.; Dinan, T.G.; Bienenstock, J.; Cryan, J.F. Ingestion of Lactobacillus strain regulates emotional behavior and central GABA receptor expression in a mouse via the vagus nerve. Proc. Natl. Acad. Sci. USA 2011, 108, 16050-16055. [CrossRef] [PubMed]

51. Savignac, H.M.; Corona, G.; Mills, H.; Chen, L.; Spencer, J.P.; Tzortzis, G.; Burnet, P.W. Prebiotic feeding elevates central brain derived neurotrophic factor, $N$-methyl-d-aspartate receptor subunits and d-serine. Neurochem. Int. 2013, 63, 756-764. [CrossRef] [PubMed]

52. Williams, S.; Chen, L.; Savignac, H.M.; Tzortzis, G.; Anthony, D.C.; Burnet, P.W. Neonatal prebiotic (BGOS) supplementation increases the levels of synaptophysin, GluN2A-subunits and BDNF proteins in the adult rat hippocampus. Synapse 2016, 70, 121-124. [CrossRef] [PubMed]

53. Sudo, N.; Chida, Y.; Aiba, Y.; Sonoda, J.; Oyama, N.; Yu, X.N.; Kubo, C.; Koga, Y. Postnatal microbial colonization programs the hypothalamic-pituitary-adrenal system for stress response in mice. J. Physiol. 2004, 558, 263-275. [CrossRef] [PubMed]

54. Nelson, E.D.; Ramberg, J.E.; Best, T.; Sinnott, R.A. Neurologic effects of exogenous saccharides: A review of controlled human, animal, and in vitro studies. Nutr. Neurosci. 2012, 15, 149-162. [CrossRef] [PubMed]

55. Messaoudi, M.; Rozan, P.; Nejdi, A.; Hidalgo, S.; Desor, D. Behavioural and cognitive effects of oligofructose-enriched inulin in rats. Br. J. Nutr. 2005, 93, S27-S30. [CrossRef] [PubMed]

56. Waworuntu, R.; Hain, H.; Chang, Q.; Thiede, L.; Hanania, T.; Berg, B. Dietary prebiotics improve memory and social interactions while reducing anxiety when provided early in life to normally developing rodents. FASEB J. 2014, 28, S637.5.

57. Sakai, F.; Ikeuchi, Y.; Urashima, T.; Fujihara, M.; Ohtsuki, K.; Yanahira, S. Effects of feeding sialyllactose and galactosylated $\mathrm{N}$-acetylneuraminic acid on swimming learning ability and brain lipid composition in adult rats. J. Appl. Glycosci. 2006, 53, 249-254. [CrossRef]

58. Wang, B.; Yu, B.; Karim, M.; Hu, H.; Sun, Y.; McGreevy, P.; Petocz, P.; Held, S.; Brand-Miller, J. Dietary sialic acid supplementation improves learning and memory in piglets. Am. J. Clin. Nutr. 2007, 85, 561-569. [PubMed]

59. Smith, A.P. The concept of well-being: Relevance to nutrition research. Br. J. Nutr. 2005, 93, S1-S5. [CrossRef] [PubMed]

60. Smith, A.P.; Sutherland, D.; Hewlett, P. An investigation of the acute effects of oligofructose-enriched inulin on subjective wellbeing, mood and cognitive performance. Nutrients 2015, 7, 8887-8896. [CrossRef] [PubMed]

61. Best, T.; Kemps, E.; Bryan, J. Saccharide effects on cognition and well-being in middle-aged adults: A randomized controlled trial. Dev. Neuropsychol. 2009, 35, 66-80. [CrossRef] [PubMed]

62. Best, T.; Howe, P.; Bryan, J.; Buckley, J.; Scholey, A. Acute effects of a dietary non-starch polysaccharide supplement on cognitive performance in healthy middle-aged adults. Nutr. Neurosci. 2015, 18, 76-86. [CrossRef] [PubMed]

63. Best, T.; Kemps, E.; Bryan, J. Association between dietary saccharide intake and self-reported memory performance in middle-aged adults. Br. J. Nutr. 2009, 101, 93-99. [CrossRef] [PubMed] 
64. Han, H.S.; Jang, J.H.; Jang, J.H.; Choi, J.S.; Kim, Y.J.; Lee, C.; Lim, S.H.; Lee, H.K.; Lee, J. Water extract of Triticum aestivum $\mathrm{L}$. and its components demonstrate protective effect in a model of vascular dementia. J. Med. Food 2010, 13, 572-578. [CrossRef] [PubMed]

65. Van den Berg, J.P.; Westerbeek, E.A.M.; Bröring-Starre, T.; Garssen, J.; van Elburg, R.M. Neurodevelopment of preterm infants at 24 months after neonatal supplementation of a prebiotic mix: A randomized trial. J. Pediatr. Gastroenterol. Nutr. 2016, 63, 270-276. [CrossRef] [PubMed]

66. Heijtz, R.D.; Wang, S.; Anuar, F.; Qian, Y.; Björkholm, B.; Samuelsson, A.; Hibberd, M.L.; Forssberg, H.; Pettersson, S. Normal gut microbiota modulates brain development and behavior. Proc. Natl. Acad. Sci. USA 2011, 108, 3047-3052. [CrossRef] [PubMed]

67. Neufeld, K.M.; Kang, N.; Bienenstock, J.; Foster, J.A. Reduced anxiety-like behavior and central neurochemical change in germ-free mice. Neurogastroenterol. Motil. 2011, 23, 255-264, e119. [CrossRef] [PubMed]

68. Mudd, A.T.; Alexander, L.S.; Berding, K.; Waworuntu, R.V.; Berg, B.M.; Donovan, S.M.; Dilger, R.N. Dietary prebiotics, milk fat globule membrane, and lactoferrin affects structural neurodevelopment in the young piglet. Front. Pediatr. 2016, 4, 4. [CrossRef] [PubMed]

69. Berding, K.; Wang, M.; Monaco, M.H.; Alexander, L S.; Mudd, A.T.; Chichlowski, M.; Waworuntu, R.V.; Berg, B.M.; Miller, M.J.; Dilger, R.N.; et al. Prebiotics and bioactive milk fractions affect gut development, microbiota and neurotransmitter expression in piglets. J. Pediatr. Gastroenterol. Nutr. 2016, in press. [CrossRef] [PubMed]

70. Tarr, A.J.; Galley, J.D.; Fisher, S.E.; Chichlowski, M.; Berg, B.M.; Bailey, M.T. The prebiotics 3'sialyllactose and $6^{\prime}$ sialyllactose diminish stressor-induced anxiety-like behavior and colonic microbiota alterations: Evidence for effects on the gut-brain axis. Brain. Behav. Immun. 2015, 50, 166-177. [CrossRef] [PubMed]

71. Schmidt, K.; Cowen, P.J.; Harmer, C.J.; Tzortzis, G.; Errington, S.; Burnet, P.W. Prebiotic intake reduces the waking cortisol response and alters emotional bias in healthy volunteers. Psychopharmacology 2015, 232, 1793-1801. [CrossRef] [PubMed]

72. Bercik, P.; Denou, E.; Collins, J.; Jackson, W.; Lu, J.; Jury, J.; Deng, Y.; Blennerhassett, P.; Macri, J.; McCoy, K.D.; et al. The intestinal microbiota affect central levels of brain-derived neurotropic factor and behavior in mice. Gastroenterology 2011, 141, 599-609. [CrossRef] [PubMed]

73. Buie, T.; Campbell, D.B.; Fuchs, G.J.; Furuta, G.T.; Levy, J.; VandeWater, J.; Whitaker, A.H.; Atkins, D.; Bauman, M.L.; Beaudet, A.L.; et al. Evaluation, diagnosis, and treatment of gastrointestinal disorders in individuals with ASDs: A consensus report. Pediatrics 2010, 125, S1-S18. [CrossRef] [PubMed]

74. Adams, J.B.; Johansen, L.J.; Powell, L.D.; Quig, D.; Rubin, R.A. Gastrointestinal flora and gastrointestinal status in children with autism-comparisons to typical children and correlation with autism severity. BMC Gastroenterol. 2011, 11, 22. [CrossRef] [PubMed]

75. De Angelis, M.; Piccolo, M.; Vannini, L.; Siragusa, S.; De Giacomo, A.; Serrazzanetti, D.I.; Cristofori, F.; Guerzoni, M.E.; Gobbetti, M.; Francavilla, R. Fecal microbiota and metabolome of children with autism and pervasive developmental disorder not otherwise specified. PLOS ONE 2013, 8, e76993.

76. Lefranc-Millot, C.; Guérin-Deremaux, L.; Wils, D.; Neut, C.; Miller, L.E.; Saniez-Degrave, M.H. Impact of a resistant dextrin on intestinal ecology: How altering the digestive ecosystem with NUTRIOSE ${ }^{\circledR}$, a soluble fibre with prebiotic properties, may be beneficial for health. J. Int. Med. Res. 2012, 40, 211-224. [CrossRef] [PubMed]

77. Nankova, B.B.; Agarwal, R.; MacFabe, D.F.; La Gamma, E.F. Enteric bacterial metabolites propionic and butyric acid modulate gene expression, including CREB-dependent catecholaminergic neurotransmission, in PC12 cells-possible relevance to autism spectrum disorders. PLoS ONE 2014, 9, e103740. [CrossRef] [PubMed]

78. Hsiao, E.Y.; McBride, S.W.; Hsien, S.; Sharon, G.; Hyde, E.R.; McCue, T.; Codelli, J.A.; Chow, J.; Reisman, S.E.; Petrosino, J.F.; et al. Microbiota modulate behavioral and physiological abnormalities associated with neurodevelopmental disorders. Cell 2013, 155, 1451-1463. [CrossRef] [PubMed]

79. Gloor, G.B.; Reid, G. Compositional analysis: A valid approach to analyze microbiome high-throughput sequencing data. Can. J. Microbiol. 2016, 1-12. [CrossRef] [PubMed]

80. Ong, J.P.; Aggarwal, A.; Krieger, D.; Easley, K.A.; Karafa, M.T.; Van Lente, F.; Arroliga, A.C.; Mullen, K.D. Correlation between ammonia levels and the severity of hepatic encephalopathy. Am. J. Med. 2003, 114, 188-193. [CrossRef] 
81. Müller, J.B.; Guggenheim, P.; Haemmerli, U.P. Treatment of chronic portal-systemic encephalopathy with lactulose. Lancet 1966, 287, 890-893. [CrossRef]

82. Prasad, S.; Dhiman, R.K.; Duseja, A.; Chawla, Y.K.; Sharma, A.; Agarwal, R. Lactulose improves cognitive functions and health-related quality of life in patients with cirrhosis who have minimal hepatic encephalopathy. Hepatology 2007, 45, 549-559. [CrossRef] [PubMed]

83. Gluud, L.L.; Vilstrup, H.; Morgan, M.Y. Dietary prebiotics, milk fat globule membrane, and lactoferrin affects structural neurodevelopment in the young piglet. Cochrane Database Syst. Rev. 2016. [CrossRef]

84. Shukla, S.; Shukla, A.; Mehboob, S.; Guha, S. Meta-analysis: The effects of gut flora modulation using prebiotics, probiotics and synbiotics on minimal hepatic encephalopathy. Aliment. Pharmacol. Ther. 2011, 33, 662-671. [CrossRef] [PubMed]

85. Elkington, S.G.; Floch, M.H.; Conn, H.O. Lactulose in the treatment of chronic portal-systemic encephalopathy. N. Engl. J. Med. 1969, 281, 408-412. [CrossRef] [PubMed]

86. Weber, F.L. Lactulose and combination therapy of hepatic encephalopathy: The role of the intestinal microflora. Dig. Dis. Basel Switz. 1996, 14, 53-63. [CrossRef]

87. Blanc, P.; Daures, J.P.; Rouillon, J.M.; Peray, P.; Pierrugues, R.; Larrey, D.; Gremy, F.; Michel, H. Lactitol or lactulose in the treatment of chronic hepatic encephalopathy: Results of a meta-analysis. Hepatol. Baltim. Md. 1992, 15, 222-228. [CrossRef]

88. Cammà, C.; Fiorello, F.; Tinè, F.; Marchesini, G.; Fabbri, A.; Pagliaro, L. Lactitol in treatment of chronic hepatic encephalopathy. Dig. Dis. Sci. 1993, 38, 916-922. [CrossRef] [PubMed]

89. Clarke, S.T.; Green-Johnson, J.M.; Brooks, S.P.J.; Ramdath, D.D.; Bercik, P.; Avila, C.; Inglis, G.D.; Green, J.; Yanke, L.J.; Selinger, L.B.; Kalmokoff, M. $\beta 2-1$ fructan supplementation alters host immune responses in a manner consistent with increased exposure to microbial components: Results from a double-blinded, randomised, cross-over study in healthy adults. Br. J. Nutr. 2016, 115, 1748-1759. [CrossRef] [PubMed]

90. Lomax, A.R.; Cheung, L.V.Y.; Tuohy, K.M.; Noakes, P.S.; Miles, E.A.; Calder, P.C. ß2-1 fructans have a bifidogenic effect in healthy middle-aged human subjects but do not alter immune responses examined in the absence of an in vivo immune challenge: Results from a randomised controlled trial. Br. J. Nutr. 2012, 108, 1818-1828. [CrossRef] [PubMed]

91. Firmansyah, A.; Pramita, G.; Carrie Fassler, A.; Haschke, F.; Link-Amster, H. Improved humoral response to measles vaccine in infants receiving infant cereal with fructo-oligosaccharides. J. Pediatr. Gastroenterol. Nutr. 2001, 31, A521.

92. Lomax, A.R.; Cheung, L.V.; Noakes, P.S.; Miles, E.A.; Calder, P.C. Inulin-type $\beta 2-1$ fructans have some effect on the antibody response to seasonal influenza vaccination in healthy middle-aged humans. Nutr. Immunol. 2015, 6, 490. [CrossRef] [PubMed]

93. Langkamp-Henken, B.; Bender, B.S.; Gardner, E.M.; Herrlinger-Garcia, K.A.; Kelley, M.J.; Murasko, D.M.; Schaller, J.P.; Stechmiller, J.K.; Thomas, D.J.; Wood, S.M. Nutritional formula enhanced immune function and reduced days of symptoms of upper respiratory tract infection in seniors. J. Am. Geriatr. Soc. 2004, 52, 3-12. [CrossRef] [PubMed]

94. Vos, A.P.; Knol, J.; Stahl, B.; M'rabet, L.; Garssen, J. Specific prebiotic oligosaccharides modulate the early phase of a murine vaccination response. Int. Immunopharmacol. 2010, 10, 619-625. [CrossRef] [PubMed]

95. Samal, L.; Chaturvedi, V.B.; Saikumar, G.; Somvanshi, R.; Pattanaik, A.K. Prebiotic potential of Jerusalem artichoke (Helianthus tuberosus L.) in Wistar rats: Effects of levels of supplementation on hindgut fermentation, intestinal morphology, blood metabolites and immune response. J. Sci. Food Agric. 2015, 95, 1689-1696. [CrossRef] [PubMed]

96. Ahmed, S.F.; Farheen, A.; Muzaffar, A.; Mattoo, G.M. Prevalence of diarrhoeal disease, its seasonal and age variation in under-fives in Kashmir, India. Int. J. Health Sci. 2008, 2, 126-133.

97. Saavedra, J.; Tschernia, A.; Moore, N.; Abi-Hanna, A.; Coletta, F.; Emenhiser, C.; Yolken, R. Gastro-intestinal function in infants consuming a weaning food supplemented with oligofructose, a prebiotic. J. Pediatr. Gastroenterol. Nutr. 1999, 29, 513. [CrossRef]

98. Tschernia, A.; Moore, N.; Abi-Hanna, A.; Yolken, R.; Coletta, F.; Emenhiser, C.; Saavedra, J. Effects of long-term consumption of a weaning food supplemented with oligofructose, a prebiotic, on general infant health status. J. Pediatr. Gastroenterol. Nutr. 1999, 29, 503. [CrossRef]

99. Osborn, D.A.; Sinn, J.K. Prebiotics in infants for prevention of allergy. Cochrane Database Syst. Rev. 2013, 3, CD006474. [PubMed] 
100. Grüber, C.; van Stuijvenberg, M.; Mosca, F.; Moro, G.; Chirico, G.; Braegger, C.P.; Riedler, J.; Boehm, G.; Wahn, U. Reduced occurrence of early atopic dermatitis because of immunoactive prebiotics among low-atopy-risk infants. J. Allergy Clin. Immunol. 2010, 126, 791-797. [CrossRef] [PubMed]

101. Moro, G.; Arslanoglu, S.; Stahl, B.; Jelinek, J.; Wahn, U.; Boehm, G. A mixture of prebiotic oligosaccharides reduces the incidence of atopic dermatitis during the first six months of age. Arch. Dis. Child. 2006, 91, 814-819. [CrossRef] [PubMed]

102. Boyle, R.J.; Tang, M.L.; Chiang, W.C.; Chua, M.C.; Ismail, I.; Nauta, A.; Hourihane, J.O.; Smith, P.; Gold, M.; Ziegler, J.; et al. Prebiotic-supplemented partially hydrolysed cow's milk formula for the prevention of eczema in high-risk infants: A randomized controlled trial. Allergy 2016, 71, 701-710. [CrossRef] [PubMed]

103. Van Esch, B.C.; Schouten, B.; de Kivit, S.; Hofman, G.A.; Knippels, L.M.; Willemsen, L.E.; Garssen, J. Oral tolerance induction by partially hydrolyzed whey protein in mice is associated with enhanced numbers of Foxp3+ regulatory T-cells in the mesenteric lymph nodes. Pediatr. Allergy Immunol. 2011, 22, 820-826. [CrossRef] [PubMed]

104. Sprenger, N.; Odenwald, H.; Kukkonen, A.K.; Kuitunen, M.; Savilahti, E.; Kunz, C. FUT2-dependent breast milk oligosaccharides and allergy at 2 and 5 years of age in infants with high hereditary allergy risk. Eur. J. Nutr. 2016, 1-9. [CrossRef] [PubMed]

105. Kukkonen, K.; Savilahti, E.; Haahtela, T.; Juntunen-Backman, K.; Korpela, R.; Poussa, T.; Tuure, T.; Kuitunen, M. Probiotics and prebiotic galacto-oligosaccharides in the prevention of allergic diseases: A randomized, double-blind, placebo-controlled trial. J. Allergy Clin. Immunol. 2007, 119, 192-198. [CrossRef] [PubMed]

106. De Kivit, S.; Saeland, E.; Kraneveld, A.D.; van de Kant, H.J.; Schouten, B.; van Esch, B.C.; Knol, J.; Sprikkelman, A.B.; van der Aa, L.B.; Knippels, L.M.; et al. Galectin-9 induced by dietary synbiotics is involved in suppression of allergic symptoms in mice and humans. Allergy 2012, 67, 343-352. [CrossRef] [PubMed]

107. Schouten, B.; van Esch, B.C.; Hofman, G.A.; Boon, L.; Knippels, L.M.; Willemsen, L.E.; Garssen, J. Oligosaccharide-induced whey-specific CD25(+) regulatory T-cells are involved in the suppression of cow milk allergy in mice. J. Nutr. 2010, 140, 835-841. [CrossRef] [PubMed]

108. Hogenkamp, A.; Thijssen, S.; van Vlies, N.; Garssen, J. Supplementing pregnant mice with a specific mixture of nondigestible oligosaccharides reduces symptoms of allergic asthma in male offspring. J. Nutr. 2015, 145, 640-646. [CrossRef] [PubMed]

109. Vos, A.P.; van Esch, B.C.; Stahl, B.; M’Rabet, L.; Folkerts, G.; Nijkamp, F.P.; Garssen, J. Dietary supplementation with specific oligosaccharide mixtures decreases parameters of allergic asthma in mice. Int. Immunopharmacol. 2007, 7, 1582-1587. [CrossRef] [PubMed]

110. Soh, J.Y.; Huang, C.H.; Chiang, W.C.; Llanora, G.V.; Lee, A.J.; Loh, W.; Chin, Y.L.; Tay, V.Y.; Chan, Y.H.; Dianne, D.; et al. Anaphylaxis to galacto-oligosaccharides-An evaluation in an atopic population in Singapore. Allergy 2015, 70, 1020-1023. [CrossRef] [PubMed]

111. Toward, R.; Montandon, S.; Walton, G.; Gibson, G.R. Effect of prebiotics on the human gut microbiota of elderly persons. Gut Microbes 2012, 3, 57-60. [CrossRef] [PubMed]

112. Guigoz, Y.; Rochat, F.; Perruisseau-Carrier, G.; Rochat, I.; Schiffrin, E.J. Effects of oligosaccharide on the faecal flora and non-specific immune system in elderly people. Nutr. Res. 2002, 22, 13-25. [CrossRef]

113. Vulevic, J.; Drakoularakou, A.; Yaqoob, P.; Tzortzis, G.; Gibson, G.R. Modulation of the fecal microflora profile and immune function by a novel trans-galactooligosaccharide mixture (B-GOS) in healthy elderly volunteers. Am. J. Clin. Nutr. 2008, 88, 1438-1446. [PubMed]

114. Vulevic, J.; Juric, A.; Walton, G.E.; Claus, S.P.; Tzortzis, G.; Toward, R.E.; Gibson, G.R. Influence of galacto-oligosaccharide mixture (B-GOS) on gut microbiota, immune parameters and metabonomics in elderly persons. Br. J. Nutr. 2015, 114, 586-595. [CrossRef] [PubMed]

115. Asarat, M.; Apostolopoulos, V.; Vasiljevic, T.; Donkor, O. Short-chain fatty acids produced by synbiotic mixtures in skim milk differentially regulate proliferation and cytokine production in peripheral blood mononuclear cells. Int. J. Food Sci. Nutr. 2015, 66, 755-765. [CrossRef] [PubMed]

116. Valcheva, R.; Hotte, N.; Gillevet, P.; Sikaroodi, M.; Thiessen, A.; Madsen, K.L. Soluble dextrin fibers alter the intestinal microbiota and reduce proinflammatory cytokine secretion in male IL-10-deficient mice. J. Nutr. 2015, 145, 2060-2066. [CrossRef] [PubMed] 
117. Brown, G.D.; Gordon, S. Immune recognition: A new receptor for $\beta$-glucans. Nature 2001, 413, 36-37. [CrossRef] [PubMed]

118. Herre, J.; Gordon, S.; Brown, G.D. Dectin-1 and its role in the recognition of beta-glucans by macrophages. Mol. Immunol. 2004, 40, 869-876. [CrossRef] [PubMed]

119. Hong, K.B.; Jeong, M.; Han, K.S.; Kim, J.H.; Park, Y.; Suh, H.J. Photoprotective effects of galacto-oligosaccharide and/or Bifidobacterium longum supplementation against skin damage induced by ultraviolet irradiation in hairless mice. Int. J. Food Sci. Nutr. 2015, 66, 923-930. [CrossRef] [PubMed]

120. Kano, M.; Masuoka, N.; Kaga, C.; Sugimoto, S.; Iizuka, R.; Manabe, K.; Sone, T.; Oeda, K.; Nonaka, C.; Miyazaki, K.; et al. Consecutive intake of fermented milk containing Bifidobacterium breve strain Yakult and galacto-oligosaccharides benefits skin condition in healthy adult women. Biosci. Microbiota Food Health 2013, 32, 33-39. [CrossRef] [PubMed]

121. Miyazaki, K.; Masuoka, N.; Kano, M.; Iizuka, R. Bifidobacterium fermented milk and galacto-oligosaccharides lead to improved skin health by decreasing phenols production by gut microbiota. Benef. Microbes 2014, 5, 121-128. [CrossRef] [PubMed]

122. Kawakami, K.; Makino, I.; Asahara, T.; Kato, I.; Onoue, M. Dietary galacto-oligosaccharides mixture can suppress serum phenol and p-cresol levels in rats fed tyrosine diet. J. Nutr. Sci. Vitaminol. 2005, 51, 182-186. [CrossRef] [PubMed]

123. Mozaffarian, D.; Benjamin, E.J.; Go, A.S.; Arnett, D.K.; Blaha, M.J.; Cushman, M.; Das, S.R.; de Ferranti, S.; Després, J.P.; Fullerton, H.J.; et al. Heart disease and stroke statistics-2016 update. A report from the American heart association. Circulation 2015. [CrossRef] [PubMed]

124. Letexier, D.; Diraison, F.; Beylot, M. Addition of inulin to a moderately high-carbohydrate diet reduces hepatic lipogenesis and plasma triacylglycerol concentrations in humans. Am. J. Clin. Nutr. 2003, 77, 559-564. [PubMed]

125. Forcheron, F.; Beylot, M. Long-term administration of inulin-type fructans has no significant lipid-lowering effect in normolipidemic humans. Metabolism 2007, 56, 1093-1098. [CrossRef] [PubMed]

126. Russo, F.; Chimienti, G.; Riezzo, G.; Pepe, G.; Petrosillo, G.; Chiloiro, M.; Marconi, E. Inulin-enriched pasta affects lipid profile and $\mathrm{Lp}$ (a) concentrations in Italian young healthy male volunteers. Eur. J. Nutr. 2008, 47, 453. [CrossRef] [PubMed]

127. Brighenti, F. Dietary fructans and serum triacylglycerols: A meta-analysis of randomized controlled trials. J. Nutr. 2007, 137, 2552S-2556S. [PubMed]

128. Jackson, K.G.; Lovegrove, J.A. Impact of probiotics, prebiotics and synbiotics on lipid metabolism in humans. Nutr. Aging 2013, 1, 181-200.

129. Vogt, J.A.; Ishii-Schrade, K.B.; Pencharz, P.B.; Jones, P.J.; Wolever, T.M. L-rhamnose and lactulose decrease serum triacylglycerols and their rates of synthesis, but do not affect serum cholesterol concentrations in men. J. Nutr. 2006, 136, 2160-2166. [PubMed]

130. Jenkins, D.J.; Wolever, T.M.; Jenkins, A.; Brighenti, F.; Vuksan, V.; Rao, A.V.; Cunnane, S.C.; Ocana, A.; Corey, P.; Vezina, C. Specific types of colonic fermentation may raise low-density-lipoprotein-cholesterol concentrations. Am. J. Clin. Nutr. 1991, 54, 141-147. [PubMed]

131. Vulevic, J.; Juric, A.; Tzortzis, G.; Gibson, G.R. A mixture of trans-galactooligosaccharides reduces markers of metabolic syndrome and modulates the fecal microbiota and immune function of overweight adults. J. Nutr. 2013, 143, 324-331. [CrossRef] [PubMed]

132. Tiwari, U.; Cummins, E. Meta-analysis of the effect of $\beta$-glucan intake on blood cholesterol and glucose levels. Nutrition 2011, 27, 1008-1016. [CrossRef] [PubMed]

133. Beynen, A.C.; Buechler, K.F.; Van der Molen, A.J.; Geelen, M.J. The effects of lactate and acetate on fatty acid and cholesterol biosynthesis by isolated rat hepatocytes. Int. J. Biochem. 1982, 14, 165-169. [CrossRef]

134. Wolever, T.M.; Brighenti, F.; Royall, D.; Jenkins, A.L.; Jenkins, D.J. Effect of rectal infusion of short chain fatty acids in human subjects. Am. J. Gastroenterol. 1989, 84, 1027-1033. [PubMed]

135. Mortensen, P.B.; Holtug, K.; Rasmussen, H.S. Short-chain fatty acid production from mono- and disaccharides in a fecal incubation system: Implications for colonic fermentation of dietary fiber in humans. J. Nutr. 1988, 118, 321-325. [PubMed]

136. Wolever, T.M.; Spadafora, P.J.; Cunnane, S.C.; Pencharz, P.B. Propionate inhibits incorporation of colonic [1,2-13C]acetate into plasma lipids in humans. Am. J. Clin. Nutr. 1995, 61, 1241-1247. [PubMed] 
137. Tarantino, G.; Finelli, C. Systematic review on intervention with prebiotics/probiotics in patients with obesity-related nonalcoholic fatty liver disease. Future Microbiol. 2015, 10, 889-902. [CrossRef] [PubMed]

138. Lambert, J.E.; Parnell, J.A.; Eksteen, B.; Raman, M.; Bomhof, M.R.; Rioux, K.P.; Madsen, K.L.; Reimer, R.A. Gut microbiota manipulation with prebiotics in patients with non-alcoholic fatty liver disease: A randomized controlled trial protocol. BMC Gastroenterol. 2015, 15, 169. [CrossRef] [PubMed]

(C) 2016 by the authors; licensee MDPI, Basel, Switzerland. This article is an open access article distributed under the terms and conditions of the Creative Commons Attribution (CC-BY) license (http:/ / creativecommons.org/licenses/by/4.0/). 